\title{
First description of Adenovirus, Enterovirus, Rotavirus and Torque teno virus in water samples collected from the Arroio Dilúvio, Porto Alegre, Brazil
}

\author{
Vecchia, AD. ${ }^{a, b}$, Fleck, JD. ${ }^{a, b}$, Comerlato, J. ${ }^{c}$, Kluge, M. ${ }^{b}$, Bergamaschi, B. ${ }^{c}$, Da Silva, JVS. , \\ Da Luz, RB. ${ }^{b}$, Teixeira, TF. ${ }^{b}$, Garbinatto, GN. ${ }^{d}$, Oliveira, DV. ${ }^{d}$, Zanin, JG. ${ }^{d}$, Van der Sand, S. ${ }^{d}$, \\ Frazzon, APG. ${ }^{d}$, Franco, AC. ${ }^{c}$, Roehe, PM. ${ }^{c, e}$ and Spilki, FR. ${ }^{a, b *}$ \\ aPrograma de Pós-Graduação em Qualidade Ambiental, Universidade Feevale, \\ CEP 93352-000, Novo Hamburgo, RS, Brazil \\ bLaboratório de Microbiologia Molecular, Instituto de Ciências da Saúde, Universidade Feevale, \\ CEP 93352-000, Novo Hamburgo, RS, Brazil \\ 'Laboratório de Virologia, Departamento de Microbiologia, Instituto de Ciências Básicas da Saúde, \\ Universidade Federal do Rio Grande do Sul - UFRGS, Av. Sarmento Leite, 500, CEP 90050-170, Porto Alegre, RS, Brazil

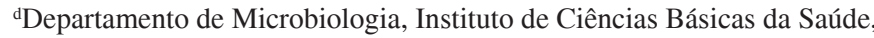 \\ Universidade Federal do Rio Grande do Sul - UFRGS, Av. Sarmento Leite, 500, CEP 90050-170, Porto Alegre, RS, Brazil \\ "Instituto de Pesquisa Veterinária "Desidério Finamor" - IPVDF, \\ Fundação Estadual de Pesquisa Agropecuária - FEPAGRO-Saúde Animal, Estrada do Conde, 6000, \\ CEP 92990-000, Eldorado do Sul, RS, Brazil \\ *e-mail: fernandors@feevale.br
}

Received May 11, 2011 - Accepted July 14, 2011 - Distributed May 31, 2012

(With 1 figure)

\begin{abstract}
Adenovirus (AdV), enterovirus (EV), genogroup A rotaviruses (GARV) and Torque teno virus (TTV) are non-enveloped viral agents excreted in feces and so may contaminate water bodies. In the present study, the molecular detection of these viruses was performed in samples of surface water collected from the Arroio Dilúvio, a waterstream that crosses the city of Porto Alegre, RS, Brazil, receiving great volumes of non-treated sewage from a large urban area. Sampling was performed during 2009, in three different occasions (January, April and September). The highest detection rate was observed for EV (64.28\%), followed by TTV (28.57\%) and AdV (21.43\%). Rotaviruses were not detected. More than on kind of tested virus was detected in five (35.71\%) of 14 samples. January was the month with the highest viral detection rate, being all samples, collected in this month, positive for at least one group of tested virus. The correlation between the detection of these different viral agents and environmental factors is discussed. To the knowledge of the authors, this is the first description of viral genomes in water samples taken from the Arroio Dilúvio, Porto Alegre (Brazil).
\end{abstract}

Keywords: adenovirus, enterovirus, rotavirus, Torque teno virus, viral analysis of water.

\section{Primeira descrição de Adenovírus, Enterovírus, Rotavírus e Torque teno vírus em amostras de água coletadas do Arroio Dilúvio, Porto Alegre, Brasil}

\begin{abstract}
Resumo
Adenovírus (AdV), enterovírus (EV), rotavírus (GARV) e Torque teno vírus (TTV) são vírus não envelopados, excretados nas fezes, podendo, assim, contaminar corpos hídricos. No presente estudo, a detecção molecular desses agentes foi realizada em amostras de águas superficiais provenientes do Arroio Dilúvio, o qual cruza a cidade de Porto Alegre-RS, Brasil. As amostras foram coletadas em três meses diferentes (janeiro, abril e setembro) do ano de 2009. A maior taxa de detecção viral foi observada para EV (64,28\%), seguida por TTV (28,57\%) e AdV (21,43\%). Rotavírus não foi detectado. Foi verificada presença simultânea de dois grupos virais em cinco $(35,71 \%)$ das 14 amostras analisadas. Janeiro foi o mês com a maior taxa de detecção viral, sendo todas as amostras, coletadas nesse mês, positivas para, no mínimo, um grupo viral em estudo. A correlação entre a detecção desses diferentes agentes virais e os fatores ambientais é discutida. Conforme conhecimento dos autores, essa é a primeira descrição de genomas virais em amostras de água provenientes do Arroio Dilúvio, Porto Alegre, Brasil.
\end{abstract}

Palavras-chave: adenovirus, enterovírus, rotavirus, Torque teno virus, análise virológica da água. 


\section{Introduction}

Water quality may be greatly affected by the presence of pathogenic microorganisms derived from fecal pollution. Currently, the microbiological monitoring of water is mainly done by detection of total and fecal coliforms (WHO, 2008). Nevertheless, the lack of these pathogens does not exclude the putative fecal contamination with different viruses excreted in feces from both ill and asymptomatic individuals (Goyal et al., 1984; Jiang and Chu, 2004; Fong et al., 2005). These agents are often collectively named enteric viruses, whereas they are excreted by fecal route and their replication occur in the gastrointestinal tract of the hosts.

The majority of these viruses is non-enveloped, which makes them highly resistant in the water environment (Sobsey and Meschke, 2003; Bosch et al., 2006). The most commonly studied species of enteric viruses are enterovirus (EV), adenovirus (AdV), genogroup A rotaviruses (GARV), hepatitis A and E viruses and more recently, norovirus (Leclerc et al., 2002; Fong and Lipp, 2005; Abdel-Moety et al., 2008; Gibson et al., 2011). Similarly to enteric viruses, Torque teno virus (TTV), an emerging virus discovered from hepatitis patients and healthy persons as well, has a similar behaviour: it is relatively resistant to heat inactivation and also excreted by the fecal route (Bendinelli et al., 2001).

Unlike microorganisms routinely analysed, such as Escherichia coli, viruses remain infectious for longer periods in the environment (Sobsey and Meschke, 2003). Additionally, non-enveloped viruses are more resistant to decontamination processes used in both drinking and wastewater treatments as well as being more species-specifical than bacteria, which may indicate them as candidates for microbial source tracking (Noble et al., 2003; Fong et al., 2005). Therefore, the analysis of viruses in conjunction with bacteria may be advantageous for detection and identification of sources for fecal contamination.

Among enteric virus, AdV and EV have been suggested particularly as efficient indicators for the monitoring of fecal contamination (Hot et al., 2003; Fong and Lipp, 2005). AdV are members of Adenoviridae family - and can cause gastroenteritis, conjunctivitis, cystitis, as well as respiratory infections (ICTV, 2009; Lenaerts et al., 2008). When compared with other enteric viruses, AdV show higher resistance to UV light inactivation used in drinking and wastewater treatments (Gerba et al., 2002; Nwachuku et al., 2005). Enteroviruses belong to the Enterovirus genus of the Picornaviridae family, order Picornavirales (ICTV, 2009). Most of these viruses cause asymptomatic infections in humans; however, some may be involved with mild respiratory illness, aseptic meningitis, acute flaccid paralysis, myocardits and others clinical outcomes (Pallansch and Roos, 2001). Both enteroviruses and adenoviruses occur especially in children and immunocompromised hosts (Fong and Lipp, 2005; Palacios and Oberste, 2005).

Rotaviruses are members of the Reoviridae family, genus Rotavirus (ICTV, 2009). The genogroup A within the
Rotavirus genus is by far recognised as the most important etiologic agent of severe diarrhea illness of infants and young children worldwide and vaccination is now being widely used for protection of children (Caprioli et al., 1996; Midthun and Kapikian, 1996; Kapikian et al., 2001).

TTV is currently classified within the Anelloviridae family (ICTV, 2009). It may infect many vertebrate species, including humans. To date, however, there is no consensus about the role of TTV infection and overt of clearly noticeable disease in human beings.

Arroio Dilúvio is a canalised waterstream that crosses Porto Alegre city, the Southern-most state capital in Brazil, with approximately 1.500 .000 inhabitants. The canalised portion of Arroio Dilúvio comprises a path of approximately $12 \mathrm{~km}$, flowing into the Lake Guaíba, which is the main source of water supply for Porto Alegre (Porto Alegre, 2011). In 1998, 446 thousand inhabitants of Porto Alegre contributed to the sub-basin of the Arroio Dilúvio, which corresponded to one third of the population of the city (Menegat, 1998). So, the present study aimed to evaluate the viral contamination of surface water collected from Arroio Dilúvio through detection of AdV, EV, GARV and TTV genomes.

\section{Material and Methods}

\subsection{Study area}

The samples were collected from five points along the course of Arroio Dilúvio, which traverses a path of about $17 \mathrm{~km}$ from its origin until it reaches the Lake Guaíba (Menegat, 1998). The location of sampling points is shown in Figure 1.

\subsection{Water sample collection}

Water samples $(500 \mathrm{~mL})$ were collected aseptically, taken directly from the superficial water, in sterilised glass bottles. The samples were transported to the laboratory under refrigeration $\left(4^{\circ} \mathrm{C}\right)$, and were kept under this condition until sample concentration. The sampling occurred in 2009, in three different dates: January 27, April 27 and September 1 .

\subsection{Sample concentration}

Putative viral particles present on the samples were concentrated using an adsorption-elution method with negatively charged membranes (HA, Millipore, USA), as described previously by Katayama et al. (2002) with minor modifications. Briefly, $500 \mathrm{~mL}$ of each water sample was mixed with $0.3 \mathrm{~g} \mathrm{MgCl}_{2}$ and $\mathrm{pH}$ adjusted to 5.0 with $10 \% \mathrm{HCl}$ Subsequently, the resulting mixture was filtered through a type HA negatively charged sterile membrane ( $0.45 \mu \mathrm{m}$ pore size; $47 \mathrm{~mm}$ diameter). The membrane was rinsed with $87.5 \mathrm{~mL}$ of $0.5 \mathrm{~mm} \mathrm{H}_{2} \mathrm{SO}_{4}(\mathrm{pH} 3.0$ ), followed by elution of viral particles adsorbed to the membrane with $2.5 \mathrm{~mL}$ of $1 \mathrm{~mm} \mathrm{NaOH}$ ( $\mathrm{pH} 10.5$ ). The filtrate was then neutralised with $12.5 \mu \mathrm{L}$ of $50 \mathrm{~mm} \mathrm{H}_{2} \mathrm{SO}_{4}$ and $12.5 \mu \mathrm{L}$ of 
100x Tris-EDTA (TE) buffer. The resulting mixture was aliquoted and stored at $-80^{\circ} \mathrm{C}$ until further processing.

\subsection{Viral nucleic acid extraction}

Viral nucleic acids (RNA, EV and GARV; DNA, AdV and TTV) were extracted from $400 \mu \mathrm{L}$ of the concentrated sample using the RTP ${ }^{\circledR}$ DNA/RNA Virus Mini Kit (Invitek, Berlin, Germany) according to the manufacturer's instructions.
The viral RNA or DNA so obtained was kept at $-80{ }^{\circ} \mathrm{C}$ until analysis.

\subsection{Polymerase chain reaction $(P C R)$ protocols for the detection of enteric viruses}

For EV and GARV, an additional step was performed before amplification, i.e. synthesis of cDNA, which was achieved with a High Capacity cDNA Reverse

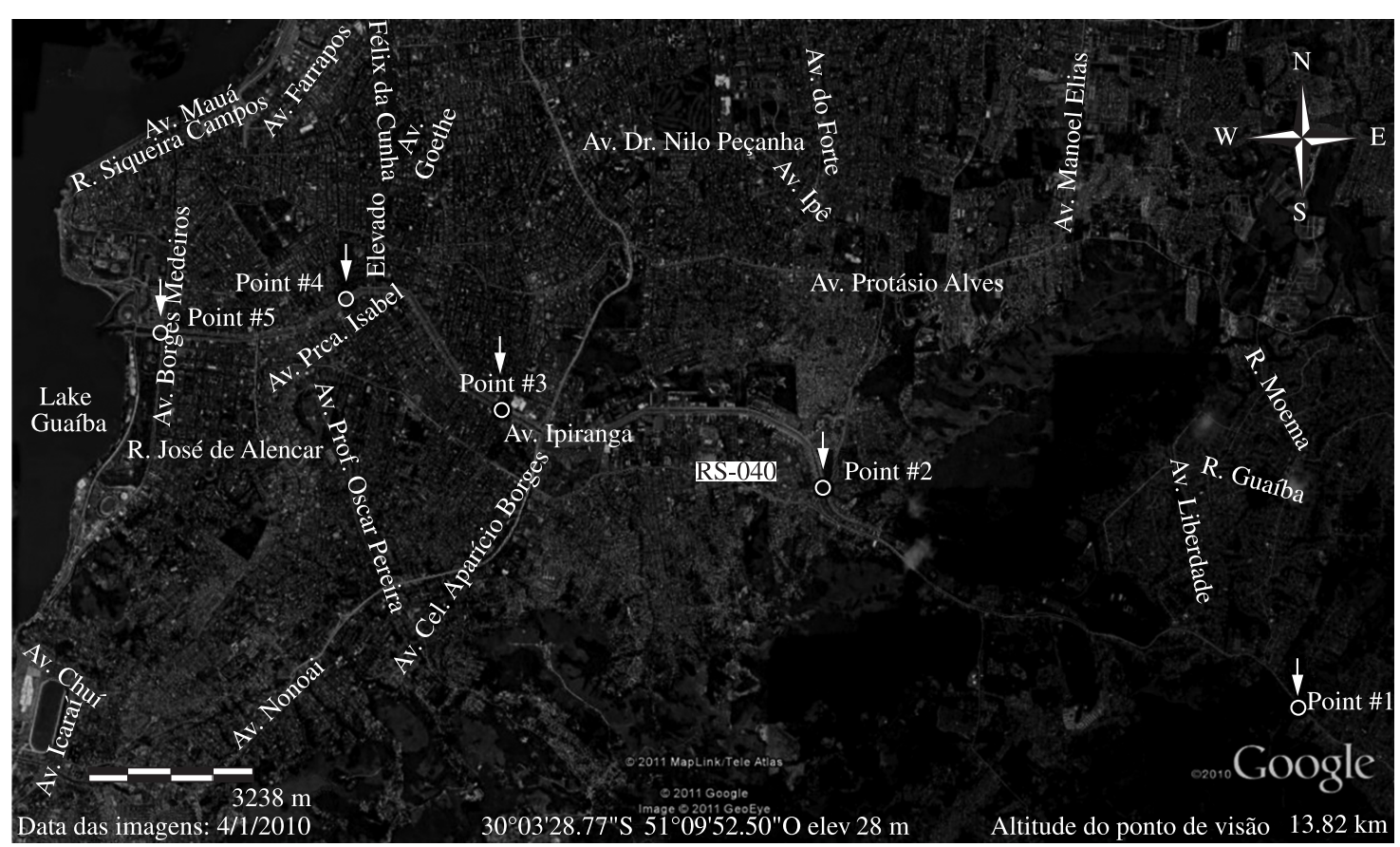

Figure 1. Satellite view of Porto Alegre, showing the collection points along the Arroio Dilúvio from the source (Point 1 , East) to the mouth (Point 5, West) (shown as dots and pointed by white arrows). Please note the intense urbanisation from Point 2 onwards. Figure made with the aid of Google Earth $\operatorname{Pro}^{\mathrm{tm}}$.

Table 1. Primers and conditions used for amplification of AdV, EV, GARV and TTV in PCR.

\begin{tabular}{|c|c|c|c|c|c|c|c|}
\hline \multirow{2}{*}{ Viruses } & \multirow{2}{*}{$\begin{array}{c}\text { Target } \\
\text { gene }\end{array}$} & \multicolumn{3}{|c|}{ Primer } & \multirow{2}{*}{ Position } & \multirow{2}{*}{$\begin{array}{l}\text { Annealing } \\
\text { temperature }\end{array}$} & \multirow{2}{*}{$\begin{array}{c}\text { Amplicon } \\
\text { length } \\
\text { (bp) }\end{array}$} \\
\hline & & Name & Sequence & Polarity & & & \\
\hline \multirow[t]{2}{*}{$\mathrm{AdV}$} & Hexon & VTB2-HAdVCf & 5'-GAGACGTACTTCAGCCTGAAT-3' & Sense & $106-126^{\mathrm{a}}$ & $55^{\circ} \mathrm{C}$ & 101 \\
\hline & & VTB2-HAdVCr & 5'-GATGAACCGCAGCGTCAA-3' & Reverse & $190-207^{\mathrm{a}}$ & & \\
\hline \multirow[t]{2}{*}{$\mathrm{EV}$} & 5'UTR & ENT-F1 & 5'-CCTCCGGCCCCTGAATG-3' & Sense & $443-459^{b}$ & $56^{\circ} \mathrm{C}$ & 116 \\
\hline & & ENT-R2 & 5'-ACACGGACACCCAAAGTAG-3' & Reverse & $541-559^{c}$ & & \\
\hline \multirow[t]{2}{*}{ GARV } & VP6 & $\begin{array}{l}\text { ROTAFEEVALE - } \\
\text { FW }\end{array}$ & 5'-GATGTCCTGTACTCCTTGT-3' & Sense & $7-25^{\mathrm{d}}$ & $54{ }^{\circ} \mathrm{C}^{\mathrm{f}}$ & 160 \\
\hline & & $\begin{array}{l}\text { ROTAFEEVALE - } \\
\text { REV }\end{array}$ & 5'-GGTAGATTACCAATTCCTCC-3' & Reverse & $148-167^{\mathrm{d}}$ & & \\
\hline \multirow[t]{3}{*}{ TTV } & ORF2 & $\mathrm{F} 1$ & 5'-GGGAGCTCAAGTCCTCATTTG-3' & Sense & $221-241^{\mathrm{e}}$ & $59{ }^{\circ} \mathrm{C}$ & 102 \\
\hline & & $\mathrm{F} 2$ & 5'-GGGCCWGAAGTCCTCATTAG-3' & Sense & $170-189^{e}$ & & \\
\hline & & Rev & 5'-GCGGCATAAACTCAGCCATTC-3' & Reverse & $252-272^{e}$ & & \\
\hline
\end{tabular}

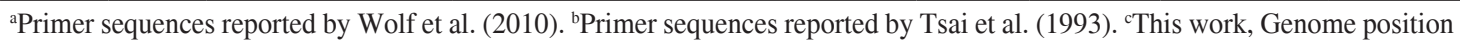

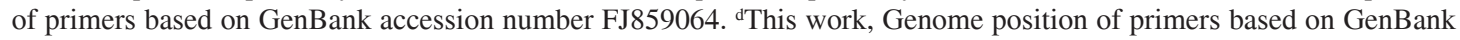
accession number HM348746. ${ }^{\mathrm{e}}$ This work, Genome position of primers based on GenBank accession number FN687866. ${ }^{\mathrm{f}}$ Initial annealing temperature, which was decreased by $0.5^{\circ} \mathrm{C}$ at each of the 39 subsequent cycles (Touchdown-PCR). 
Transcription commercial kit (Applied Biosciences, USA), with the aid of random primers, following the manufacturer's instructions.

After previous assays to achieve optimal conditions, PCR reactions were standardised and carried out as follows: a) $\mathrm{AdV}$ and GARV: $50 \mu \mathrm{L}$ reaction mixtures consisting $25 \mu \mathrm{L}$ of $\mathrm{GoTaq}^{\circledR}$ Green Master Mix (Promega), $18 \mu \mathrm{L}$ of nuclease-free water, $1 \mu \mathrm{L}$ of each primer $(20 \mathrm{pM})$ and $5 \mu \mathrm{L}$ of nucleic acid; b) EV: $25 \mu \mathrm{L}$ final volume containing $12,5 \mu \mathrm{L}$ of $2 x$ PCR Master Mix ${ }^{\text {tm }}$ (LGCbio, Brazil), 7,5 $\mu \mathrm{L}$ of nuclease-free water, $1 \mu \mathrm{L}$ of each primer $(20 \mathrm{pM})$ and $3 \mu \mathrm{L}$ of cDNA product; c) TTV: final volume of $50 \mu \mathrm{L}$ containing $25 \mu \mathrm{L}$ of $2 x$ PCR Master Mix ${ }^{\mathrm{tm}}$ (LGCbio, Brazil), $22,5 \mu \mathrm{L}$ of nuclease-free water, $0.5 \mu \mathrm{L}$ of each primer $(20 \mathrm{pM})$ and $1.0 \mu \mathrm{L}$ of extracted DNA. DNase/RNase free water was used as a negative control during all PCR reactions. The positive controls used in amplifications were Poliovirus-1 (Sabin strain), kindly provided by Dr. Carlos Nozawa; AdV types 2 and 5, kindly provided by Dr. Célia Barardi; Human-GARV (VP6 I-2 Genotype), isolated from a clinical sample collected in the municipality of Porto Alegre, and a 100-fold diluted solution containing a TTSV (Torque Teno Sus Virus) cloned genome. The sequences of the primers and their location in the viruses' genomes are given in Table 1.

Amplification was performed using a thermal cycler (MultiGene, Labnet International, USA). The PCR conditions were optimised for each virus group and were as follows: a) $\mathrm{AdV}$ : $98^{\circ} \mathrm{C}$ for 7 minutes, 40 cycles of $94{ }^{\circ} \mathrm{C}$ for 1 minute, $55^{\circ} \mathrm{C}$ for 1 minute, $72{ }^{\circ} \mathrm{C}$ for 1 minute; b) $\mathrm{EV}$ : $98{ }^{\circ} \mathrm{C}$ for 5 minutes, 35 cycles of $94^{\circ} \mathrm{C}$ for 1 minute, $56{ }^{\circ} \mathrm{C}$ for 1 minute, $72{ }^{\circ} \mathrm{C}$ for 1 minute; c) GARV: $94{ }^{\circ} \mathrm{C}$ for 5 minutes, 40 cycles of $94{ }^{\circ} \mathrm{C}$ for 1 minute, $54{ }^{\circ} \mathrm{C}$ for 1 minute (which was decreased by $0.5^{\circ} \mathrm{C}$ at each of the 39 subsequent cycles), $72{ }^{\circ} \mathrm{C}$ for 1 minute; d) TTV: $94{ }^{\circ} \mathrm{C}$ for 2 minutes, 40 cycles of $94{ }^{\circ} \mathrm{C}$ for 1 minute, $59{ }^{\circ} \mathrm{C}$ for 30 seconds, $72{ }^{\circ} \mathrm{C}$ for 30 seconds. After cycles all reactions were left at $72{ }^{\circ} \mathrm{C}$ for 7 minutes for final elongation.

The sensibility of the assays was determined using 10fold serial dilutions of each DNA/RNA standard. EV-PCR has shown to detect a minimum of 0.316 tissue culture infective doses $\left(\mathrm{TCID}_{50}\right)$ of experimentally contaminated water, to AdV-PCR this value was $0.562 \mathrm{TCID}_{50}$. To determine the TTV-PCR sensibility an additional step was required before serial dilution, i.e. plasmid cloning. This assay was able to detect 10 DNA plasmids copies. On the specific case of GARV, the amount of DNA used for amplification was measured by comparison with Low Mass DNA ladder (Invitrogen, USA) and determined as $200 \mathrm{ng}$.

After the reactions, PCR products were stained with nontoxic fluorescent dye, Blue Green (LGCBio, Brazil), analyzed by electrophoresis on $2 \%(\mathrm{w} / \mathrm{v}$ ) agarose gel and visualised under an ultraviolet (UV) light source.

\section{Results}

Water samples were taken at five sampling sites along the waterstream Arroio Dilúvio, in three different dates, January 27, April 27 and September 1. Fourteen water samples were analysed by conventional PCR for the presence of AdV, EV, GARV and TTV. EV showed the highest detection rate $(64.28 \%)$, followed by TTV (28.57\%) and AdV (21.43\%). All samples were negative for GARV. Results are summarised in Table 2.

January was the month with the highest viral detection rate. All sampling points showed the presence of at least one group of virus, with detection of $\mathrm{EV}$ in four out of five samples analysed. The massive presence of EV was also observed in April, which was found in all sampling points. The lowest viral detection rate was recognised in

Table 2. Detection of AdV, EV, GARV and TTV genome in water samples collected from the Arroio Diluvio, Porto Alegre, Brazil.

\begin{tabular}{|c|c|c|c|c|c|c|c|c|c|c|c|c|c|}
\hline \multirow{2}{*}{\multicolumn{2}{|c|}{$\begin{array}{c}\text { Collection date } \\
\text { Virus }\end{array}$}} & \multicolumn{4}{|c|}{ January } & \multicolumn{4}{|c|}{ April } & \multicolumn{4}{|c|}{ September } \\
\hline & & \multirow{2}{*}{$\frac{\text { AdV }}{-}$} & \multirow{2}{*}{$\frac{\text { EV }}{+}$} & \multirow{2}{*}{$\begin{array}{c}\text { GARV } \\
-\end{array}$} & \multirow{2}{*}{$\begin{array}{c}\text { TTV } \\
-\end{array}$} & \multirow{2}{*}{$\begin{array}{c}\text { AdV } \\
-\end{array}$} & \multirow{2}{*}{$\frac{\text { EV }}{+}$} & \multirow{2}{*}{$\begin{array}{c}\text { GARV } \\
-\end{array}$} & \multirow{2}{*}{$\frac{\text { TTV }}{-}$} & \multirow{2}{*}{$\begin{array}{c}\text { AdV } \\
-\end{array}$} & \multirow{2}{*}{$\begin{array}{c}\mathbf{E V} \\
-\end{array}$} & \multirow{2}{*}{$\begin{array}{c}\text { GARV } \\
-\end{array}$} & \multirow{2}{*}{$\frac{\text { TTV }}{-}$} \\
\hline Harvesting & $\mathrm{P \# 1}$ & & & & & & & & & & & & \\
\hline points & $\mathrm{P \# 2}$ & + & - & - & + & - & + & - & - & - & - & - & - \\
\hline & $\mathrm{P} \# 3$ & + & + & - & - & - & + & - & + & + & - & - & - \\
\hline & P\#4 & - & + & $\mathrm{N} / \mathrm{T}$ & - & - & + & - & - & - & - & - & - \\
\hline & $\mathrm{P} \# 5$ & - & + & - & + & - & + & - & + & $\mathrm{N} / \mathrm{T}$ & $\mathrm{N} / \mathrm{T}$ & $\mathrm{N} / \mathrm{T}$ & $\mathrm{N} / \mathrm{T}$ \\
\hline
\end{tabular}

+ (Detected). - (Not detected). N/T (Not tested).

Table 3. Monthly meteorological data recorded for Porto Alegre city in January, April, August and September 2009. Source: $8^{\circ}$ Meteorology District - Inmet, Porto Alegre, Brazil.

\begin{tabular}{|c|c|c|c|c|}
\hline & January & April & August & September \\
\hline Precipitation $(\mathrm{mm} \mathrm{Hg})$ & 169.6 & 31 & 264.5 & 293 \\
\hline Mean temperature $\left({ }^{\circ} \mathrm{C}\right)$ & 23.5 & 20.9 & 16.7 & 17.1 \\
\hline Maximum temperature $\left({ }^{\circ} \mathrm{C}\right)$ & 29.0 & 27.6 & 23.1 & 22.0 \\
\hline Minimum temperature $\left({ }^{\circ} \mathrm{C}\right)$ & 19.4 & 16.4 & 12.0 & 14.0 \\
\hline Relative humidity & 76 & 74 & 77 & 82 \\
\hline
\end{tabular}


September, with only one positive water sample, in which was detected AdV.

Among the samples analysed, point 3 showed the highest viral detection, being detected AdV and EV in January, EV and TTV in April and AdV in September. This point is located in a region considered of medium impact, according to Menegat (1998), since it is in the middle section of the course and receives wastewater from an urban region. However, viral detection (EV) was observed even at the source of the waterstream (point 1 - into Saint Hilaire Park), in January and April.

\section{Discussion}

Porto Alegre city, the southernmost large urban area in Brazil, is crossed by Arroio Dilúvio, a canalised waterstream that flows into the Lake Guaíba, the main source of water supply of this same municipality. This waterstream receives untreated sewage of at least one third of the population of the city. In the present study, the fecal contamination in surface water was evaluated by detection of AdV, EV, GARV and TTV. High viral detection rates were identified in January and April, being EV the main virus group detected. However, all samples collected in September were negative for EV. These events were not related with the mass Polio Vaccination Campaigns (implemented twice a year in Brazil by the Ministry of Health), which, in 2009, were held in June $20^{\text {th }}$ and September $19^{\text {th }}$ (DATASUS, 2011).

Meteorological data, such as precipitation, mean temperature, maximum and minimum temperatures and relative humidity (Table 3), were analysed in order to interpret those results. With respect to monthly precipitation data, apparently there could be a relationship between the difference in the EV frequency and precipitation values. Nevertheless, when daily precipitation data were available, it was verified that no association can be performed, since all samples were collected in the absence of rain, condition observed during, at least, six consecutive days before sampling days. Other parameters may be associated to viral detection rate, such as water temperature, air humidity, solar insolation, wind speed, wind direction and turbidity (Wong et al., 2009). However, in this case, the anthropogenic factor, i.e. discharge of sewage in Arroio Dilúvio, is the major factor to viral detection.

In this study, AdV was detected only in three water samples (two in January and one in September), i.e. $21.43 \%$. Although many reports have been published regarding higher incidence of $\mathrm{AdV}$ when compared to $\mathrm{EV}$ in water samples, maybe because $\mathrm{AdV}$ genome is composed by double-stranded DNA, so it is potentially more stable to adverse conditions (as, for example, UV irradiation), some authors have verified higher EV detection rates. Fong et al. (2005) evaluate the presence of EV, AdV and bovine enterovirus (BEV) in water samples from Altamaha River (Georgia). The authors detected EV in $57 \%$ of surface water samples, while only $37 \%$ of samples were positive for AdV. Slightly higher EV detection was also related to Lee et al. (2005), who detected EV in $33.3 \%$ of surface water samples collected from Han River (Seoul, Korea) and AdV in $30.4 \%$ of samples. Chapron et al. (2000) verified a similar situation, with higher EV detection (58.6\%) than AdV (48.3\%) in surface water samples.

Despite the high prevalence of TTV (92\%) having been reported by Diniz-Mendes et al. (2008) in samples taken from a stream located in Manaus (Brazil), the TTV detection rate found in this study was not high, since only $28.57 \%$ of water samples analysed were positive for TTV. Other studies also showed lower TTV levels in water than those observed by Diniz-Mendes et al. (2008). For example, Verani et al. (2006) detected TTV presence in only $25 \%$ of water samples from a river in Italy. A lower TTV detection rate has been verified by Haramoto et al. (2005), who detected TTV in $5 \%$ of surface water samples, in Japan.

Bacterial analysis was performed to water samples collected from Arroio Dilúvio. The results showed the presence of Enteroccocus, Staphylococcus, E. coli, Shighella, Salmonella (data not shown, personal communication). Enteroccocus, E. coli, Shighella, Salmonella were detected in all sampling points, while Staphylococcus were found in four sampling points. Detection of E. coli and enteric viruses in all points tested demonstrates the presence of fecal contamination in Arroio Dilúvio. Since this waterstream flowing into the Lake Guaíba, which is the main source of water supply for Porto Alegre, the need for the development of appropriate wastewater treatment is emphasized, as well as water treatment, mainly considering the high resistance of enteric viruses in the water environment. Further, the host specificity of enteric viruses suggest that they can be promising markers of microbial source tracking, as well as the chance of the human population getting viral infections through contaminated water being largely determined by the degree of exposure to human sewage. Therefore, it is advisable to include enteric viruses in water quality monitoring programmes, which facilitate the identification of the source of contamination.

This is the first report showing the description of viral genomes in water samples taken from the Arroio Dilúvio, Porto Alegre (Brazil), to the knowledge of the authors. According to the obtained results, the enterovirus genus may be advisable as a marker of viral contamination in this particular environment, in view of the high prevalence observed. Nevertheless, further studies should be conducted in order to perform more frequent samplings and to evaluate the viral viability in cell cultures, as well as to characterize the genomic sequences found.

Acknowledgements - Financial support for this work was from the Universidade Feevale and Brazilian Research Agencies: Conselho Nacional de Desenvolvimento Científico e Tecnológico (CNPq), Coordenação de Aperfeiçoamento de Pessoal de Nível Superior (CAPES) and Fundação de Amparo à Pesquisa do Estado do Rio Grande do Sul (FAPERGS). We would like to thank Dr. Carlos Nozawa (Departamento de Microbiologia, UEL, Brazil) who kindly supplied the Poliovirus-1 (Sabin strain) and Dr. Célia Barardi (Departamento de Microbiologia, Imunologia e Parasitologia, UFSC, Brazil) for kindly providing the Adenovirus types 2 and 5. F.R.S., A.C.F. and P.M.R. are Conselho Nacional de Desenvolvimento Científico e Tecnológico (CNPq) research fellows. 


\section{References}

ABDEL-MOETY, NM., AL-FASSI, FA. and ALI, MA., 2008. Health aspects of virological water quality: an overview review. Journal of Applied Sciences Research, vol. 4, no. 10, p. 1205-1215.

BENDINELLI, M., PISTELLO, M., MAGGI, F., FORNAI, C., FREER, G. and VATTERONI, ML., 2001. Molecular properties, biology, and clinical implications of TT virus, a recently identified widespread infectious agent of humans. Clinical Microbiology Reviews, vol. 14, no. 1, p. 98-113. PMid:11148004. PMCid:88963. http://dx.doi.org/10.1128/CMR.14.1.98-113.2001

BOSCH, A., PINTÓ, RM. and ABAD, FX., 2006. Survival and transport f enteric viruses in the environmental. Universitat de Barcelona. p. 151-188. Available from: <http://www.ub.edu/ microbiologia/viruse/papers/GOY6.pdf>. Access in: 20 abr. 2011.

CAPRIOLI, A., PEZZELLA, C., MORELLI, R., GIAMMANCO, A., ARISTA, S., CROTTI, D., FACCHINI, M., GUGLIELMETTI, P., PIERSIMONI, C. and LUZZI, I., 1996. Enteropathogens associated with childhood diarrhea in Italy. The Italian Study Group on Gastrointestinal Infections. Pediatric Infectious Disease, vol. 15 , no. 10 , p. $876-883$.

CHAPRON, CD., BALLESTER, NA., FONTAINE, JH., FRADES, CN. and MARGOLIN, AB., 2000. Detection of Astroviruses, Enteroviruses, and Adenovirus Types 40 and 41 in Surface Waters Collected and Evaluated by the Information Collection Rule and an Integrated Cell Culture-Nested PCR Procedure. Applied and Environmental Microbiology, vol. 66, no. 6, p. 2520-2525. PMid:10831432. PMCid:110573. http://dx.doi.org/10.1128/ AEM.66.6.2520-2525.2000

DATASUS, 2011. Campanha Nacional De Vacinação Contra Polio dos Municípios do Estado Rio Grande do Sul. Available from: <http://pni.datasus.gov.br/>. Access in: 20 abr. 2011.

DINIZ-MENDES, L., DE PAULA, VS., LUZ, SLB. and NIEL, C., 2008. High prevalence of human Torque teno vírus in streams crossing the city of Manaus, Brazilian Amazon. Journal of Applied Microbiology, vol. 105, p. 51-58. PMid:18217932. http://dx.doi. org/10.1111/j.1365-2672.2007.03720.x

FONG, TT. and LIPP, EK., 2005. Enteric viruses of humans and animals in aquatic environments: health risks, detection, and potential water quality assessment tools. Microbiology and Molecular Biology Reviews, vol. 69, no. 2, p. 357-371. PMid:15944460. PMCid:1197419. http://dx.doi.org/10.1128/ MMBR.69.2.357-371.2005

FONG, TT., GRIFFIN, DW. and LIPP, EK., 2005. Molecular assays for targeting human and bovine enteric viruses in coastal waters and their application for library-independent source tracking. Applied and Environmental Microbiology, vol. 71, no. 4, p. 2070-2078. PMid:15812040. PMCid:1082535. http://dx.doi. org/10.1128/AEM.71.4.2070-2078.2005

GERBA, CP., GRAMOS, DM. and NWACHUKU, N., 2002. Comparative inactivation of enteroviruses and adenovirus 2 by UV light. Applied and Environmental Microbiology, vol. 68, no. 10, p. 5167-5169. PMid:12324370. PMCid:126408. http:// dx.doi.org/10.1128/AEM.68.10.5167-5169.2002

GIBSON, KE., OPRYSZKO, MC., SCHISSLER, JT., GUO, Y. and SCHWAB, KJ., 2011. Evaluation of human enteric viruses in surface water and drinking water resources in Southern Ghana. The American Journal of Tropical Medicine and Hygiene, vol. 84, p. 20-29. PMid:21212196. PMCid:3005515. http://dx.doi. org/10.4269/ajtmh.2011.10-0389

GOYAL, SM., ADAMS, WN., O'MALLEY, ML. and LEAR, DW., 1984. Human Pathogenic Viruses at Sewage Sludge Disposal Sites in the Middle Atlantic Region. Applied and Environmental Microbiology, vol. 48, no. 4, p. 758-763. PMid:6334495. PMCid:241609.

HARAMOTO, E., KATAYAMA, H., OGUMA, K. and OHGAKI, S., 2005. Application of cation-coated filter method to detection of noroviruses, enteroviruses, adenoviruses and torque teno viruses in the Tamagawa River in Japan. Applied and Environmental Microbiology, vol. 71, no. 5, p. 2403-2411. PMid:15870327. PMCid:1087541. http://dx.doi.org/10.1128/AEM.71.5.24032411.2005

HOT, D., LEGEAY, O., JACQUES, J., GANTZER, C., CAUDRELIER, Y., GUYARD, K., LANGE, M. and ANDRÉOLETTI, L., 2003. Detection of somatic phages, infectious enteroviruses and enterovirus genomes as indicators of human enteric viral pollution in surface water. Water Research, vol. 37, p. 4703-4710. http://dx.doi.org/10.1016/S0043-1354(03)00439-1

International Committee on Taxonomy of Viruses - ICTV, 2009. Available from: <http://www.ictvonline.org/virusTaxonomy. asp?version=2009>. Access in: 20 abr. 2011.

JIANG, SC. and CHU, W., 2004. PCR detection of pathogenic viruses in southern California urban rivers. Journal of Applied Microbiology, vol. 97, p. 17-28. PMid:15186438. http://dx.doi. org/10.1111/j.1365-2672.2004.02269.x

KAPIKIAN, AZ., HOSHINO Y. and CHANOCK, RM., 2001. Rotaviruses. In KNIPPE, DM., HOWLEY, PM. and GRIFFIN, DE. (Eds.). Fields virology. 4th ed. Philadelphia: Lippincott Williams \& Wilkins. p. 1787-1833.

KATAYAMA, H., SHIMASAKI, A. and OHGAKI, S., 2002. Development of a virus concentration method and its application to detection of enterovirus and Norwalk virus from coastal seawater. Applied and Environmental Microbiology, vol. 68, no. 3, p. 1033-1039. PMid:11872447. PMCid:123733. http:// dx.doi.org/10.1128/AEM.68.3.1033-1039.2002

LECLERC, H., SCHWARTZBROD, L. and DEI-CAS, E., 2002. Microbial agents associated with waterborne. Critical Reviews in Microbiology, vol. 28, no. 4, p. 371- 409. PMid:12546197. http:// dx.doi.org/10.1080/1040-840291046768

LEE, SH., LEE, C., LEE, KW., CHO, HB. and KIM, SJ., 2005. The simultaneous detection of both enteroviruses and adenoviruses in environmental water samples including tap water with an integrated cell culture-multiplex-nested PCR procedure. Journal of Applied Microbiology, vol. 98, p. 1020-1029. PMid:15836470. http://dx.doi.org/10.1111/j.1365-2672.2004.02496.x

LENAERTS, L., DE CLERCQ, E. and NAESENS, L., 2008. Clinical features and treatment of adenovirus infections. Reviews in Medical Virology, vol. 8, no. 6, p. 357-374. PMid:18655013. http://dx.doi.org/10.1002/rmv.589

MENEGAT, R., 1998. Atlas Ambiental de Porto Alegre. Porto Alegre: Editora UFRGS.

MIDTHUN, K. and KAPIKIAN, AZ., 1996. Rotavirus vaccines: an overview. Clinical Microbiology Reviews, vol. 9, no. 3, p. 423-434. PMid:8809469. PMCid:172902.

NOBLE, RT., ALLEN, SM., BLACKWOOD, AD., CHU, W., JIANG, SC., LOVELACE, GL., SOBSEY, MD., STEWART, JR. 
and WAIT, DA., 2003. Use of viral pathogens and indicators to differentiate between human and non-human fecal contamination in a microbial source tracking comparison study. Journal of Water and Health, vol. 1, no. 4, p. 195-207. PMid:15382724.

NWACHUKU, N., GERBA, CP., OSWALD, A. and MASHADI, FD., 2005. Comparative Inactivation of Adenovirus Serotypes by UV Light Disinfection. Applied and Environmental Microbiology, vol. 71, no. 9, p. 5366-5636. PMid:16151167. PMCid:1214670. http://dx.doi.org/10.1128/AEM.71.9.5633-5636.2005

PALACIOS, G. and OBERSTE, MS., 2005. Enteroviruses as agents of emerging infectious diseases. Journal Neurovirology, vol. 11, p. 424-433. PMid:16287683. http://dx.doi. org/10.1080/13550280591002531

PALLANSCH, MA. and ROOS, RP., 2001. Enteroviruses: polioviruses, coxsackieviruses, echoviruses, and newer enteroviruses. In KNIPPE, DM., HOWLEY, PM. (Eds.). Fields Virology. 4th ed. Philadelphia: Lippincott Williams and Wilkins. p. 723-75.

Porto Alegre (Município). Departamento de Esgotos Pluviais - DEP, 2011. O Arroio Dilúvio. Available from: $<$ http:// www2.portoalegre.rs.gov.br/dep/default.php?p_secao=71>. Access in: 20 abr. 2011

SOBSEY, MD. and MESCHKE, JS., 2003. Virus survival in the environment with special attention to survival in sewage droplets and other environmental media of fecal or respiratory origin. World Health Organization. Available from: <http:// www.unc.edu/courses/2008spring/envr/421/001/WHO_ VirusSurvivalReport_21Aug2003.pdf>. Access in: 20 abr. 2011.
TSAI, YL., SOBSEY, MD., SANGERMANO, LR. and PALMER, CJ., 1993. Simple method of concentrating enteroviruses and hepatitis A virus from sewage and ocean water for rapid detection by reverse transcriptase-polymerase chain reaction. Applied and Environmental Microbiology, vol. 59, no. 10, p. 3488-3491. PMid:7504433. PMCid:182480.

VERANI, M., CASINI, B., BATTISTINI, R., PIZZI, F., ROVINI, E. and CARDUCCI. A., 2006. One-year monthly monitoring of Torque teno virus (TTV) in river water in Italy. Water Science Technology, vol. 54, no. 3, p. 191-195. http://dx.doi.org/10.2166/ wst. 2006.468

WHO, 2008. Guidelines for Drinking-water QualityRecommendations. 3rd ed. Geneva: World Health Organization. vol. 1. Available from: <http://www.who.int/water_sanitation_health/ dwq/gdwq3rev/en/>. Access in: 20 abr. 2011.

WOLF, S., HEWITT, J. and GREENING, GE., 2010. Viral multiplex quantitative PCR assays for tracking sources of fecal contamination. Applied and Environmental Microbiology, vol. 76, no. 5, p. 1388-1394. PMid:20061455. PMCid:2832383. http:// dx.doi.org/10.1128/AEM.02249-09

WONG, M., KUMAR, L., JENKINS, TM., XAGORARAKI, I., PHANIKUMAR, MS. and ROSE, JB., 2009. Evaluation of public health risks at recreational beaches in Lake Michigan via detection of enteric viruses and a human-specific bacteriological marker. Water Research, vol. 43, p. 1137-1149. PMid:19118856. http://dx.doi.org/10.1016/j.watres.2008.11.051 
